\title{
Release of Cell Wall Degrading Enzymes from Conidia of Blumeria graminis on Artificial Substrata
}

\author{
Shunji Suzuki*, Yukiko KomiYa*, Tomohiro Mitsui*, Shinji TsuYumu**, \\ Hitoshi KunOH*, Timothy L.W. CARVER*** and Ralph L. NiCHOLSON ${ }^{\dagger}$
}

\begin{abstract}
Cellulase and pectinase activities were examined in the exudates released from conidia of Blumeria graminis (Syn: Erysiphe graminis) and their germlings on two hydrophobic artificial substrata. Conidia were allowed to germinate on the substrata for 1,6 and $16 \mathrm{hr}$ for the formation of primary germ tubes, appressorial germ tubes and maturation of appressoria, respectively. The exudates released by $16 \mathrm{hr}$ after inoculation were collected by washing the substrata with $10 \mathrm{mM}$ Tris- $\mathrm{HCl}$ buffer (pH 7.0). The exudate-buffer mixture was then charged on an anion- (High Q) and a cation- (High S) exchange column. Fractions eluted with a step-wise $0.2-1.0 \mathrm{NaCl}$ gradient from a High Q column exhibited cellulase activity in a carboxylmethyl cellulose plate test and in $\rho$-nitrophenyl- $\beta$-D-cellobioside assay, but not pectinase activity in a polygalacturonic acid-yeast extract-agar plate test. Thus, cellulases are released from germlings by $16 \mathrm{hr}$ after incubation on the substrata. The exudates released at 1 and $6 \mathrm{hr}$ after inoculation also exhibited a little activity of cellulase but not of pectinase. However, the exudates from the surfaces of conidia on conidiophores which were prepared by washing with $10 \mathrm{mM}$ Tris- $\mathrm{HCl}$ buffer (pH 7.0) exhibited neither cellulase nor pectinase activities. The exudates prepared by washing conidia and germlings with $1 \mathrm{M} \mathrm{NaCl}$ contained pectinase but not cellulase activities, suggesting that pectinases may be tightly adsorbed to the surface of the conidium. Homogenates of ungerminated conidia and germlings contained cellulase and pectinase activities, indicating that some of cellulase and pectinases are present constitutively within conidia. This is the first direct evidence that conidia of a powdery mildew fungus produce cellulases and pectinases and that their germlings release cellulases. Since carboxylmethyl cellulose and $\rho$-nitrophenyl- $\beta$-D-cellobioside were used as substrates to detect cellulase activity, the cellulases shown in this paper should be considered to correspond to carboxylmethyl cellulases and exo- $\beta$-glucanases.
\end{abstract}

( Received December 19, 1997 ; Accepted February 24, 1998)

Key words : Blumeria graminis, cellulase, Erysiphe graminis, pectinase.

\section{INTRODUCTION}

Most powdery mildew fungi are ectoparasites growing on their host surfaces where they typically invade the host epidermal cell by direct penetration of the wall. In earlier investigations, dyes such as cotton blue and toluidine blue were used to demonstrate the presence of haloes around the tips of appressoria of Blumeria graminis (DC Speer) [Syn. Erysiphe graminis (DC)] on the surface of host epidermal cells ${ }^{1,6,22,23)}$. These observations suggested that the host cell wall might be degraded by enzymes released from the tip of the appressorium. Kunoh and $\mathrm{Akai}^{10)}$ studied histochemical features of halo zones induced by B. graminis f. sp. hordei (Em.
Marchal) on barley leaves in more detail by applying semi-specific reagents and reported that reducing sugars with aldehyde groups, pentoses and uronic acids accumulated specifically within the zone of the halo. Although histochemical studies suggested indirectly that powdery mildew fungi could release cell wall degrading enzymes, no direct evidence has indicated the nature of the enzymes.

Kunoh et al. ${ }^{13)}$ showed that contact with cellophane or a leaf surface rapidly stimulated conidia of $B$. graminis f. sp. hordei to release a liquid exudate. The exudate formed a film on the conidium surface and flowed outward from the conidium onto the contact surface, where it often appeared flocculate. Nicholson et al. ${ }^{17)}$ subsequently showed the liquid exudate to contain non-

* Laboratory of Plant Pathology, Faculty of Bioresources, Mie University, Tsu 514-8507, Japan 三重大学生物資源学部

** Laboratory of Plant Pathology, Faculty of Agriculture, Shizuoka University, Shizuoka 422-8529, Japan 静岡大学農 学部

*** Institute of Grasslands and Environment Research, Aberystwyth, Dyfed SY23 3EB, United Kingdom

† Department of Botany and Plant Pathology, Purdue University, West Lafayette, Indiana 47907, USA 
specific esterase activity. Ungerminated conidia released esterases in two stages following contact stimulation: the first was within 2 min after contact, and the second between 10 and $15 \mathrm{~min}$ after contact. The release of esterase was correlated with changes in conidial surface morphology and cuticular degradation of the leaf surface immediately adjacent to the conidium ${ }^{12)}$. Furthermore, Pascholati et al. ${ }^{18)}$ found that cutinase was a component of the liquid exudate released by ungerminated conidia. This is the first direct evidence that an obligately parasitic powdery mildew pathogen produces enzymes capable of degrading the cutin component of the plant cuticle. Of particular significance was the fact that the enzyme was released by conidia at the time of their contact with the host, suggesting relevance of the enzyme to the initiation of the infection process ${ }^{16)}$.

Several recent observations suggest that phenomena associated with initial stages of fungal contact with the host play a critical role in host recognition, fungal differentiation and success of infection ${ }^{14,16)}$. Thus, enzymes released from ungerminated conidia immediately after contact stimulation could have a role in the early events that influence conidium and germling morphogenesis as well as the ultimate parasite-host interactions. For this reason, we have studied the liquid exudate released by conidia as well as the adhesion of $B$. graminis conidia. In the present investigation, we examined cellulase and pectinase activities associated with ungerminated conidia and with germlings of $B$. graminis. Activity of the enzymes released from conidia incubated on a hydrophobic cellulose dialysis membrane and on a hydrophobic plastic surface was compared. We used these different substrata because recent evidence shows that $B$. graminis conidia released liquid exudate more rapidly and in greater quantity after contact with a hydrophobic plastic surface than on hydrophilic glass $^{11)}$. As described in the methods, carboxylmethyl cellulose (CMC) and $\rho$-nitrophenyl- $\beta$-D-cellobioside (PNPC) were used as substrates to detect cellulase activity; the cellulases indicated in this paper should be considered to be carboxylmethyl cellulase and exo- $\beta$ glucanase.

\section{MATERIALS AND METHODS}

Test fungus Blumeria graminis (Syn. Erysiphe graminis) f. sp. tritici, the wheat powdery mildew fungus, was used throughout. This fungus was maintained on wheat (Triticum sativum cv. Norin 1) seedlings grown in a growth chamber at $20^{\circ} \mathrm{C}$ and $70 \%$ relative humidity (RH) under light $\left(11.8 \mathrm{Wm}^{-2} / 12 \mathrm{hr} /\right.$ day $)$.

Preparation of artificial substrata Cellulose membranes $\left(11.5 \times 7.0 \mathrm{~cm}^{2}\right)$ were prepared from pieces of dialysis tubing (Sanko Jyunyaku Co.) which had been washed in boiling distilled water and then dried. Membrane pieces prepared in this way provided a relatively hydrophilic substratum. To increase the hydrophobicity of the cellulose membrane, pieces of washed/dried dialysis tubing were silanized in $2 \%$ dimethyldichlorosilane (DMS) in toluene for $2 \mathrm{~min}$, washed with $100 \%$ ethanol once and then distilled water several times to remove the toluene, and then dried overnight. Plastic coverslips (Thermanox; Nunc Inc., Naperville, USA) treated similarly with DMS provided an alternative hydrophobic substratum. A simple goniometer was used to measure the contact angle by $5 \mu \mathrm{l}$ water droplets applied to the three substrata. The contact angle is influenced by the hydrophobicity of the substratum such that a larger contact angle indicates a greater degree of hydrophobicity. Contact angles obtained from the three substrata were: unsilanized cellulose membrane $=27^{\circ}$; silanized cellulose membrane $=52^{\circ}$; silanized plastic coverslip $=80^{\circ}$. Thus, the silanized substrata were more hydrophobic than the untreated membrane.

\section{Extraction of exudates released from germlings} on artificial substrata Forty unsilanized cellulose membranes were hydrated by laying them on $2 \%$ agarose in petri plates. They were inoculated with conidia $\left(10^{3}\right.$ conidia $\left./ \mathrm{mm}^{2}\right)$ and incubated at $20^{\circ} \mathrm{C}$ in the dark for $16 \mathrm{hr}$ under high RH at the membrane surface. Some pieces of membrane were observed through the microscope to confirm that conidia had germinated and formed appressoria. After incubation, membranes were removed from the agarose, dipped in $400 \mathrm{ml}$ of $10 \mathrm{mM}$ Tris- $\mathrm{HCl}$ buffer ( $\mathrm{pH}$ 7.0) and shaken on a reciprocal shaker (30 stroke/min) at room temperature for $30 \mathrm{~min}$ to suspend germlings and release their exudates into the buffer. Germlings were removed from the suspension by a two-step filtration process, first using a glass filter (Whatman) and then a Millex GV filter (Millipore Co.). The filtrate was applied to a DEAE Sepharose column equilibrated with $10 \mathrm{mM}$ Tris- $\mathrm{HCl}$ buffer ( $\mathrm{pH}$ 7.0). The column was washed with the same buffer overnight $(1 \mathrm{ml} / \mathrm{min}$ ) with an HPLC (Shimadzu LC-9A). After the column was washed, components that had adsorbed were eluted by fractionation with a linear gradient of 0 $0.7 \mathrm{M} \mathrm{NaCl}$ (flow rate $0.80 \mathrm{ml} / \mathrm{min}$ ). Fractions, $4 \mathrm{ml}$ each, were collected for enzyme plate tests as described below.

Hydrophobic, silanized cellulose membranes and plastic coverslips were also placed on $2 \%$ agarose in petri dishes, inoculated and incubated as described previously for 1, 6 or $16 \mathrm{hr}$. Again, germling exudates were collected by shaking in $10 \mathrm{mM}$ Tris- $\mathrm{HCl}$ buffer $(\mathrm{pH} 7.0)$ before filtrates were collected. The filtrates were applied to an anion-exchange column (Econo-Pac High Q cartridge, Biorad Co.). The uncharged materials on the column were then applied to a cation-exchange column (Econo-Pac High S cartridge, Biorad Co.). Components that had been adsorbed to the column were eluted successively with $0.2,0.3,0.4,0.5$ and $1.0 \mathrm{M} \mathrm{NaCl}$. Individual fractions were concentrated to about $100 \mu \mathrm{l}$ using Centricon concentrators (Amicon Co.) and the concentrated eluents were used for enzyme assays.

To examine intracellular enzymes, germlings incubated on silanized coverslips were collected on the glass 
filter during the extraction were homogenized in liquid nitrogen with a mortar and pestle. The homogenate was then suspended in $1 \mathrm{M} \mathrm{NaCl}$ and then filtered using the two-step filtration procedure to remove conidial residue. The filtrate was then concentrated as described above and used for enzyme plate tests.

Whether or not any components were strongly adsorbed, membranes and plastic coverslips which had been washed with $10 \mathrm{mM}$ Tris- $\mathrm{HCl}$ buffer were further shaken in $1 \mathrm{M} \mathrm{NaCl}$ at room temperature for $30 \mathrm{~min}$ and left in the same solution at $4^{\circ} \mathrm{C}$ overnight. This solution was filtered using the glass and Milex filters, and the filtrate was dialyzed overnight in distilled water at $4^{\circ} \mathrm{C}$. The solution in the dialysis tube was then lyophilized. After the final product was solubilized in $3 \mathrm{ml}$ of $10 \mathrm{mM}$ Tris- $\mathrm{HCl}$ buffer ( $\mathrm{pH} 7.0$ ), the product was concentrated to about $100 \mu \mathrm{l}$ using Centricon concentrators, for use in the enzyme plate tests.

Extraction of exudates of ungerminated conidia To examine whether ungerminated conidia produce extra- or intracellular cellulases or pectinases, conidia were harvested directly from colonies on wheat leaves into $200 \mathrm{ml}$ of $10 \mathrm{mM}$ Tris- $\mathrm{HCl}$ buffer ( $\mathrm{pH} \mathrm{7.0).} \mathrm{The}$ conidial suspension was shaken on a reciprocal shaker (30 strokes/min) for $30 \mathrm{~min}$, then conidia and debris were removed by the two-step filtration process and the filtrate was applied to a High Q column as previously described. Unbound material was then applied to a High $\mathrm{S}$ column. The material that bound to the column was then eluted with a $0.2-1.0 \mathrm{M} \mathrm{NaCl}$ series as described previously. Then the final fractionated samples were concentrated to about $100 \mu \mathrm{l}$ with a Centricon and used as crude fractions of exudates from ungerminated conidia.

To obtain components which may have been strongly adsorbed on conidial surfaces, conidia collected on the glass filter during the extraction were resuspended in 20 $\mathrm{ml}$ of $1 \mathrm{M} \mathrm{NaCl}$ and shaken at room temperature for 30 min. The suspension was kept overnight at $4^{\circ} \mathrm{C}$ before conidia were removed by the two-step filtration procedure. The final filtrates were concentrated to about 100 $\mu 1$ with a Centricon and used as a $1 \mathrm{M} \mathrm{NaCl}$ extraction fraction for enzyme plate tests.

The procedures just described were designed to collect enzymes from the conidial surface. To collect cellulases and pectinases within ungerminated conidial cells, conidia trapped on the glass filter following the $1 \mathrm{M} \mathrm{NaCl}$ extraction were homogenized, then extracted as described.

Effects of extraction protocols on survival of conidia We had to determine that the procedure allowed for the collection of exudates released from conidia and the extraction of materials strongly adsorbed onto the surface of conidia without damaging conidia releasing intracellular materials into the extraction media. To determine whether damage to conidia resulted from extraction either with $10 \mathrm{mM}$ Tris- $\mathrm{HCl}$ buffer (pH 7.0) or $1 \mathrm{M} \mathrm{NaCl}$, conidia collected from glass filters after each step in the extraction protocol were resuspended in $20 \mathrm{ml}$ of either $10 \mathrm{mM}$ Tris- $\mathrm{HCl}(\mathrm{pH} 7.0)$ or $1 \mathrm{M} \mathrm{NaCl}$. The conidial suspensions were then mounted on glass slides and conidia were examined using a Zeiss Axiophoto microscope to determine whether they were turgid (undamaged) or collapsed. Furthermore, $500 \mu \mathrm{g} / \mathrm{ml}$ of fluorescent diacetate (FDA) was added to the suspension as a vital stain to assess the viability of conidia ${ }^{25}$. Viable conidia emitting a yellowgreen fluorescence were counted using the same microscope with a fluorescence attachment (filter conditions : an excitation filter $\mathrm{B}=\mathrm{IF} 4.90$, a beam splitter $\mathrm{B}=\mathrm{DM}$ $500,+0515$, a barrier filter $=530$ ) under blue light excitation. The percentage of dead and living conidia were calculated by observing 120-150 conidia. Differences in percentages of shrunken conidia and vital conidia between extractions were analyzed by Student's $t$-test.

Enzyme assay of crude and fractionated extracts To detect enzyme activities in crude and fractionated exudates, the following agar plate methods were applied. For detection of cellulase activity, carboxylmethyl cellulose (CMC) plates were prepared according to Teather and $\mathrm{Wood}^{24)}\left[\left(\mathrm{NH}_{4}\right)_{2} \mathrm{SO}_{4}, 2 \mathrm{~g} ; \mathrm{KH}_{2} \mathrm{PO}_{4}, 4\right.$ $\mathrm{g} ; \mathrm{Na}_{2} \mathrm{HPO}_{4} \cdot 7 \mathrm{H}_{2} \mathrm{O}, 11.32 \mathrm{~g} ; \mathrm{MgSO}_{4} \cdot 7 \mathrm{H}_{2} \mathrm{O}, 0.2 \mathrm{~g}$; yeast extract, $1 \mathrm{~g}$; carboxylmethyl cellulose sodium salt (CMC), $5 \mathrm{~g}$; agar, $10 \mathrm{~g} / 1$ ]. Ten $\mu 1$ of each fraction was dropped onto CMC plates, followed by incubation at room temperature overnight. An appropriate volume (ca. $2 \mathrm{ml}$ ) of $0.1 \%$ Congo red solution was poured onto the plates and kept at room temperature for $20 \mathrm{~min}$. The Congo red solution was replaced with $1 \mathrm{M} \mathrm{NaCl}$ and the plates were shaken on a reciprocal shaker for $15 \mathrm{~min}$. Regions degraded by the action of cellulases appeared as transparent background spots (Fig. 3). For detection of pectinase activity, polygalacturonic acid-yeast extractagar (PYA) plates were prepared according to Saarilahti et $a l .{ }^{20)}$ [polygalacturonic acid (Sigma), $0.7 \mathrm{~g}$; yeast extract, $1 \mathrm{~g}$; agar, $1 \mathrm{~g} / 100 \mathrm{ml}$ of $\mathrm{H}_{2} \mathrm{O}$ ]. Ten $\mu 1$ of each fraction was dropped onto PYA plates and the plates were incubated at room temperature overnight. Addition of an appropriate volume $(1 \mathrm{ml})$ of $5 \mathrm{~N} \mathrm{H}_{2} \mathrm{SO}_{4}$ revealed regions degraded by pectinases as transparent spots (Fig. 4). As positive controls, $2 \mu \mathrm{l}$ of $1 \mathrm{mg} / \mathrm{ml}$ cellulase Onozuka R-10 (Yakult Co.) and $10 \mathrm{mg} / \mathrm{ml}$ macerozyme R-10 (Yakult Co.) were applied to CMC and PYA plates, respectively.

Cellulase activity was assayed by measuring the release of $\rho$-nitrophenol from the substrate. The reaction mixture $(0.2 \mathrm{ml})$ contained $0.05 \mathrm{ml}$ of $10 \mathrm{mM} \rho$ nitrophenyl $\beta$-D-cellobioside (PNPC, Sigma), $0.1 \mathrm{ml}$ of 10 $\mathrm{mM}$ Tris- $\mathrm{HCl}(\mathrm{pH} \mathrm{7.0)}$ and $1 / 10$ volume of extracts of exudates released from ungerminated conidia and germlings on silanized plastic coverslips. The reaction was terminated by adding $0.3 \mathrm{ml}$ of $1 \mathrm{M} \mathrm{Na}_{2} \mathrm{CO}_{3}$ after incubation at $25^{\circ} \mathrm{C}$ for $20-24 \mathrm{hr}$. The release of $\rho$-nitrophenol was then monitored at $400 \mathrm{~nm}$ using a UV recording spectrophotometer (Simadzu UV-160). As a positive control, $50 \mu 1$ of cellulase Onozuka R-10 ( $1 \mathrm{mg} / \mathrm{ml})$ was 


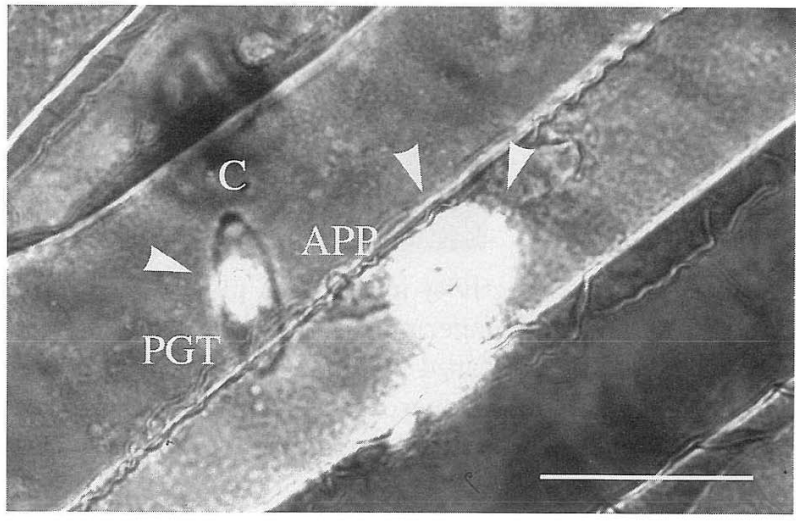

Fig. 1. Halo zones (arrow heads) induced by a primary germ tube and an appressorium of a conidium of Blumeria graminis in a wheat leaf epidermis. The stripped epidermis was stained with zincchlor-iodide $24 \mathrm{hr}$ after inoculation. Abbreviations : $\mathrm{C}=$ conidium ; $\mathrm{PGT}=$ primary germ tube ; $\mathrm{APP}=$ appressorium. Scale $\mathrm{bar}=50 \mu \mathrm{m}$.

used instead of the exudates in the reaction mixture. The activity unit of cellulase was expressed as the amount of the enzymes that increased absorbance by 0.1 per hr.

\section{RESULTS AND DISCUSSION}

In preliminary tests, stripped epidermises of wheat leaves inoculated with $B$. graminis f. sp. tritici were stained with zinc-chlor-iodide or ruthenium red $24 \mathrm{hr}$ after inoculation. Negatively-stained halo zones were observed around tips of primary germ tubes and appressoria by both stains (Fig. 1). These observations were consistent with those of earlier papers in which similar dyes were used ${ }^{1,6,10,22,23)}$. This suggested that halo zones may have been formed through the action of cellulases and/or pectinases.

Morphogenesis of germinated conidia to form normal mature appressoria occurred on untreated and silanized cellulose membranes and on the silanized Thermanox plastic coverslips. The time required for conidia to form mature appressoria on the artificial surfaces was slightly longer than on wheat leaves. The percentage of mature appressoria was $41.2 \%$ and $54.6 \%$ by $16 \mathrm{hr}$ after inoculation on silanized cellulose membranes and plastic coverslips, respectively. These percentages were similar to those found on hydrophilic, unsilanized cellulose membranes used in the current and previous studies ${ }^{8}$. Since histochemical observations suggested that cellulases and/or pectinases may be released from germlings on wheat epidermis after the formation of mature appressoria, we attempted to collect exudates from germlings on artificial substrata at $16 \mathrm{hr}$ after inoculation, when maximum appressorium formation would have occurred. The use of artificial substrata ensured that any enzymes collected were of fungal origin and avoided contamination problems implicit in such collec-

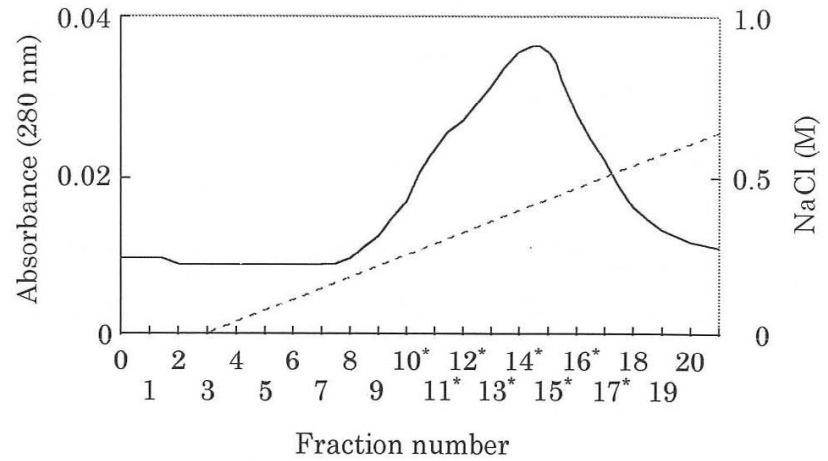

Fig. 2. The HPLC elution profile of exudates released from germlings of Blumeria graminis on unsilanized cellulose membranes. Adsorbed proteins in a DEAE Sepharose column were eluted with a linear gradient of $\mathrm{NaCl}$ from 0 to $0.7 \mathrm{M}$ in $10 \mathrm{mM}$ Tris- $\mathrm{HCl}$ buffer ( $\mathrm{pH} 7.0)$. — , eluted protein ; --.--, concentration of $\mathrm{NaCl} .{ }^{*}$ Fraction Nos. 10-17 showing cellulase activity in the CMC plate tests.

tions from inoculated plant tissues.

\section{Enzyme assay of crude extracts and exudates from ungerminated conidia and germlings on artificial substrata}

Figure 2 illustrates the elution profile from a DEAE Sepharose column of components of exudates that had been released from germlings onto unsilanized cellulose membranes. The exudates were eluted from the column with a linear $0-0.7 \mathrm{M} \mathrm{NaCl}$ gradient. Among 21 fractions obtained, fractions 10 through 17 were found to contain cellulase activities when applied to CMC plates. In contrast, no fractions exhibited pectinase activity when applied to PYA plates. These results suggest that germlings had released extracellular cellulases by $16 \mathrm{hr}$ on an artificial substratum.

Our recent evidence ${ }^{11}$ and unpublished data showed that $B$. graminis not only forms mature appressoria on hydrophobic artificial substrata, but that conidia and germ tubes release extracellular fluid more rapidly and in greater quantity than on hydrophilic artificial substrata. We took advantage of this to investigate the release of cellulases and pectinases in greater detail. Exudates, which were obtained from hydrophobic cellulose membranes and plastic coverslips and eluted with a series of $\mathrm{NaCl}$ solutions from anion- and cationexchange columns, were subjected to the CMC and PYA plate tests. Table 1 shows that extracts from hydrophobic cellulose membranes and from hydrophobic plastic coverslips which had been eluted from an anionexchange column with $0.3-0.5 \mathrm{M}$ and $0.2-0.5 \mathrm{M} \mathrm{NaCl}$, respectively, contained cellulase activity as shown by the $\mathrm{CMC}$ plate tests. Importantly, only the extracts that had been eluted from the anion-exchange column with $\mathrm{NaCl}$ were positive for cellulase activity (Table 1). The extracts eluted from the cation-exchange column did not exhibit enzyme activity (Table 1). The neutral fraction 
Table 1. Cellulase activity in exudates released from germlings of Blumeria graminis on hydrophobic artificial substrata by $16 \mathrm{hr}$ after inoculation

\begin{tabular}{|c|c|c|c|c|}
\hline \multirow{3}{*}{$\begin{array}{c}\mathrm{NaCl} \\
\text { concentration } \\
\text { for elution }\end{array}$} & \multicolumn{4}{|c|}{ Cellulase activity ${ }^{\text {a) }}$} \\
\hline & \multicolumn{2}{|c|}{ Cellulose membrane } & \multicolumn{2}{|c|}{ Plastic coverslip } \\
\hline & High $Q^{b)}$ & High $\mathrm{S}^{\mathrm{b})}$ & High Q & High S \\
\hline $0.2 \mathrm{M}$ & - & - & + & - \\
\hline $0.3 \mathrm{M}$ & ++ & - & ++ & - \\
\hline $0.4 \mathrm{M}$ & ++ & - & ++ & - \\
\hline $0.5 \mathrm{M}$ & + & - & + & - \\
\hline $1.0 \mathrm{M}$ & - & - & - & - \\
\hline
\end{tabular}

a) Transparent spots were scored, $-:$ no spot, + : small clear spot, ++ : clear spot having a larger area than that of an applied drop.

b) High Q: anion-exchange column, High S: cationexchange column.
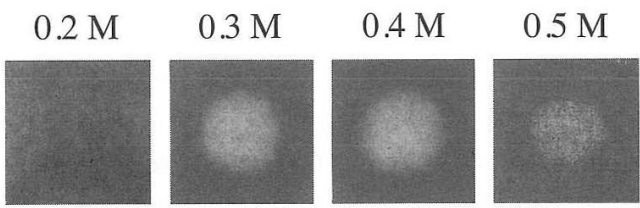

$1.0 \mathrm{M}$
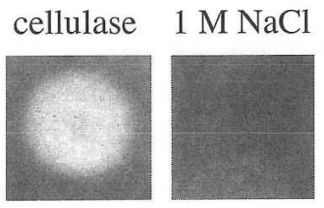

Fig. 3. Cellulase activity in the CMC plate tests. Samples were exudates of germlings of Blumeria graminis released on hydrophobic cellulose membranes. Fractions eluted with a step-wise $0.2-1.0 \mathrm{M} \mathrm{NaCl}$ gradient from an anion-exchange column were applied to CMC plates. Cellulase Onozuka $(1 \mathrm{mg} / \mathrm{ml})$ and $1 \mathrm{M} \mathrm{NaCl}$ were used as standards.

which did not adsorb to anion- and cation-exchange columns also did not exhibit enzyme activity (data not shown). Figure 3 shows representative examples of the positive cellulase activity on the CMC plates with extracts eluted from the anion-exchange column. These results indicate that cellulase activity is associated with some components that were adsorbed relatively tightly to an anion-exchange column, because fractions eluted with a broader range of $\mathrm{NaCl}$ concentrations contained cellulase activity. Fractions with cellulase activity were eluted with a slightly broader range of $\mathrm{NaCl}$ concentrations when collected from silanized plastic coverslips than when collected from the cellulose membrane (Table 1). Whether this difference is due to quantitative differences in the enzymes released or to qualitative differences (e.g. isozymes) in enzymes produced on the different substrata is uncertain. No fractions showed detectable pectinase activity in PYA plate tests (Table 3).

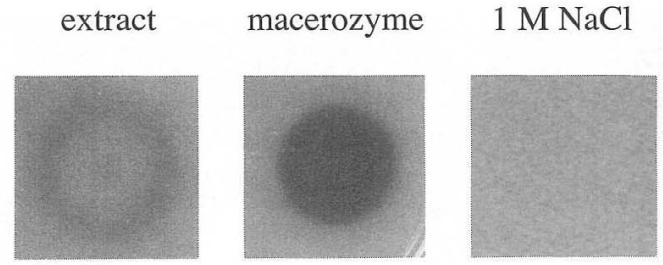

Fig. 4. Pectinase activity in the PYA plate tests. Crude extract of ungerminated conidia of Blumeria graminis released by $1 \mathrm{M} \mathrm{NaCl}$ was applied on PYA plate. Macerozyme $(10 \mathrm{mg} / \mathrm{ml})$ and $1 \mathrm{M}$ $\mathrm{NaCl}$ were used as standards.

Table 2. Cellulase activity in crude extracts and exudates from ungerminated conidia and germlings of Blumeria graminis incubated on silanized plastic coverslips for 1,6 or $16 \mathrm{hr}$

Extracts \begin{tabular}{crcc} 
Time & after & inoculation $(\mathrm{hr})$ \\
\hline $0^{\text {a) }}$ & 1 & 6 & 16
\end{tabular}

$10 \mathrm{mM}$ Tris- $\mathrm{HCl}(\mathrm{pH}$ 7.0) extraction High Q column ${ }^{\text {) }}$

$\begin{array}{lcccc}0.2 \mathrm{M}^{\mathrm{c})} & - & + & + & + \\ 0.3 \mathrm{M} & - & + & + & ++ \\ 0.4 \mathrm{M} & - & - & - & ++ \\ 0.5 \mathrm{M} & - & - & - & + \\ 1.0 \mathrm{M} & - & - & - & - \\ 00 \mathrm{lumn}^{\mathrm{b})} & & & & \\ 0.2 \mathrm{M} & - & \mathrm{ND} & \mathrm{ND} & - \\ 0.3 \mathrm{M} & - & \mathrm{ND} & \mathrm{ND} & - \\ 0.4 \mathrm{M} & - & \mathrm{ND} & \mathrm{ND} & - \\ 0.5 \mathrm{M} & - & \mathrm{ND} & \mathrm{ND} & - \\ 1.0 \mathrm{M} & - & \mathrm{ND} & \mathrm{ND} & - \\ \text { n } & - & \mathrm{ND} & \mathrm{ND} & \mathrm{ND} \\ \text { gs } & + & + & + & + \\ & & & & \end{array}$

$1 \mathrm{M} \mathrm{NaCl}$ extraction

Conidial or germlings

homogenates

a) Not inoculated. Conidia were suspended directly from colonies on wheat leaves into $10 \mathrm{mM}$ Tris- $\mathrm{HCl}$ buffer (pH 7.0).

b) High Q: anion-exchange column, High S: cationexchange column.

c) The concentration of $\mathrm{NaCl}$ for a step-wise elution from anion-exchange (High Q) and cation-exchange (High S) columns.

d) Not determined. ,,-+++ : see footnote of Table 1.

The exudates of germlings incubated on silanized plastic coverslips for $1 \mathrm{hr}$ and $6 \mathrm{hr}$ exhibited cellulase activities (Tables 2 and 4). However, cellulase activities detected at these times were much weaker than those collected from silanized plastic coverslips after $16 \mathrm{hr}$ incubation (Tables 2 and 4). Considering that primary germ tubes and appressorial germ tubes are formed by most B. graminis conidia within $1 \mathrm{hr}$ and $6 \mathrm{hr}$ after inoculation, respectively, and that appressorial germ tubes matured into appressoria by $16 \mathrm{hr}$, the release of this enzyme might be associated with appressorial maturation. 
Table 3. Pectinase activity in crude extracts and exudates from ungerminated conidia and germlings of Blumeria graminis incubated on silanized plastic coverslips for 1,6 or $16 \mathrm{hr}$

\begin{tabular}{|c|c|c|c|c|}
\hline \multirow{2}{*}{ Extracts } & \multicolumn{4}{|c|}{ Time after inoculation (hr } \\
\hline & $0^{\text {a) }}$ & 1 & 6 & 16 \\
\hline \multicolumn{5}{|c|}{$\begin{array}{c}10 \mathrm{mM} \text { Tris- } \mathrm{HCl} \text { (pH 7.0) extraction } \\
\text { High Q column }{ }^{\text {b) }}\end{array}$} \\
\hline $0.2 \mathrm{M}^{\mathrm{c})}$ & - & - & - & - \\
\hline $0.3 \mathrm{M}$ & - & - & - & - \\
\hline $0.4 \mathrm{M}$ & - & - & - & - \\
\hline $0.5 \mathrm{M}$ & - & - & - & - \\
\hline $1.0 \mathrm{M}$ & - & - & - & - \\
\hline \multicolumn{5}{|l|}{ High S column ${ }^{\text {b) }}$} \\
\hline $0.2 \mathrm{M}$ & - & $\mathrm{ND}^{\mathrm{d})}$ & ND & - \\
\hline $0.3 \mathrm{M}$ & - & ND & $\mathrm{ND}$ & - \\
\hline $0.4 \mathrm{M}$ & - & ND & $\mathrm{ND}$ & - \\
\hline $0.5 \mathrm{M}$ & - & ND & ND & - \\
\hline $1.0 \mathrm{M}$ & - & ND & ND & - \\
\hline $1 \mathrm{M} \mathrm{NaCl}$ extraction & + & ND & ND & ND \\
\hline $\begin{array}{l}\text { Conidial or germlings } \\
\text { homogenates }\end{array}$ & + & + & + & + \\
\hline
\end{tabular}

a), b), c), d) : see footnote of Table $2 .-,+$ : see footnote of Table 1.

Table 4. Cellulase activitiy in exudates released from ungerminated conidia and germlings of Blumeria graminis incubated for 1,6 or $16 \mathrm{hr}$ on silanized plastic coverslips with PNPC assay

\begin{tabular}{ccccc}
\hline \hline \multirow{2}{*}{ Extracts } & \multicolumn{4}{c}{ Specific activity (units $/ 10^{8}$ conidia) } \\
\cline { 2 - 5 } & \multicolumn{4}{c}{ Time after inoculation $(\mathrm{hr})$} \\
\cline { 2 - 5 } & $0^{\mathrm{a})}$ & 1 & 6 & 16 \\
\hline Eluted from High & column & & & \\
$0.2 \mathrm{M}^{\mathrm{c})}$ & $\mathrm{ND}$ & $\mathrm{ND}$ & $\mathrm{ND}$ & 0.061 \\
$0.3 \mathrm{M}$ & $\mathrm{ND}$ & 0.014 & $\mathrm{ND}$ & 0.055 \\
$0.4 \mathrm{M}$ & $\mathrm{ND}$ & 0.001 & 0.003 & 0.110 \\
$0.5 \mathrm{M}$ & $\mathrm{ND}$ & 0.001 & $\mathrm{ND}$ & 0.028 \\
$1.0 \mathrm{M}$ & $\mathrm{ND}$ & $\mathrm{ND}$ & $\mathrm{ND}$ & $\mathrm{ND}$ \\
Cellulase Onozuka R-10 specific activity (units/ $/ \mu \mathrm{g})$ & 0.169 \\
\hline
\end{tabular}

a), b), c) : see footnote of Table 2 .

ND : Not detected.

Inoculated silanized cellulose membranes and plastic coverslips were washed with $1 \mathrm{M} \mathrm{NaCl}$ after first shaking them in $10 \mathrm{mM}$ Tris- $\mathrm{HCl}$ buffer (pH 7.0). The $\mathrm{NaCl}$ wash fluid contained neither cellulase nor pectinase activity. This result indicates that most of the cellulases released from germlings onto both substrata was solubilized in the initial wash with Tris- $\mathrm{HCl}$ buffer. Kunoh et $a l{ }^{11)}$ reported that liquid components were released from conidia at least within $30 \mathrm{sec}$ after they contacted cellulose membranes and silanized plastic coverslips, and apparently "sticky" adhesive-like components were secreted beneath primary germ tubes and appressorial germ tubes. Light microscopy confirmed that these adhesive-like components were removed from silanized
Table 5. Effects of extraction on survival of ungerminated conidia of Blumeria graminis

\begin{tabular}{ccc}
\hline \hline Extraction & $\begin{array}{c}\text { Percentage of } \\
\text { shrunken conidia } \\
(\% \pm \mathrm{SE})\end{array}$ & $\begin{array}{c}\text { Percentage of } \\
\text { vital conidia } \\
(\% \pm \mathrm{SE})\end{array}$ \\
\hline control (no treatment) & $13.5 \pm 3.1$ & $71.4 \pm 5.7$ \\
$10 \mathrm{mM}$ Tris- $\mathrm{HCl}$ & $4.6 \pm 0.4^{\mathrm{a})}$ & $68.2 \pm 2.4^{\mathrm{b})}$ \\
$(\mathrm{pH} 7.0)$ extraction & & \\
$1 \mathrm{M} \mathrm{NaCl}$ extraction & $7.6 \pm 0.8^{\mathrm{a})}$ & $73.2 \pm 3.0^{\mathrm{b})}$ \\
\hline
\end{tabular}

a), b) No significant difference from control $(p>0.05)$.

cellulose membranes and plastic coverslips by agitation in Tris- $\mathrm{HCl}$ buffer (data not shown). Pascholati et al. ${ }^{18)}$ detected cutinase activity in the liquid released onto cellulose membranes from ungerminated $B$. graminis conidia within 30 min after contact with the membranes. Since conidia never form appressorial germ tubes within $30 \mathrm{~min}$, enzyme activity was probably associated with liquid exudate released from conidia upon their initial contact with the substratum. This conclusion is reinforced by earlier observations that demonstrated the release of non-specific esterase activity in two phases after contact, the first within $2 \mathrm{~min}$ and the second within 10 to $15 \mathrm{~min}$ of the contact of ungerminated conidia with the cellophane substratum ${ }^{17)}$.

In the present investigation, we could not determine whether the cellulases released by conidia was also associated with liquid released beneath conidia, with sticky components secreted beneath appressorial germ tubes, or with both. However, in a separate experiment we failed to detect cellulase activity when exudates were collected within $1 \mathrm{hr}$ of inoculation from silanized plastic coverslips. This may suggest that cellulases are released from primary germ tubes and appressorial germ tubes but not in the liquid exudate that is released by ungerminated conidia upon their initial contact. Additional studies are required to confirm this suggestion and to define precisely when cellulases are released.

Subsequent analyses were done to examine whether cellulases were present constitutively in ungerminated conidia or whether they were formed during some later stage of morphogenesis. Before collecting extracts from ungerminated conidia, the effects of extraction steps on survival of conidia were tested to ensure that intracellular materials were not released into the extraction media. As indicated in Table 5, when they were suspended in water approximately $13.5 \%$ of conidia appeared collapsed. However, only about $4.6 \%$ and $7.6 \%$ of conidia appeared collapsed after extraction with either $10 \mathrm{mM}$ Tris- $\mathrm{HCl}$ (pH 7.0) or $1 \mathrm{M} \mathrm{NaCl}$ extraction. Assays with fluorescein diacetate vital staining revealed that $68.2-73.2 \%$ of the conidia were alive after treatment with either buffer or $\mathrm{NaCl}$. Because these percentages were not significantly different from those of controls where conidia were exposed only to water, conidia were considered to be undamaged by any of the extraction media, suggesting that contamination of 
intraconidial materials into the extraction media was negligible, if any.

We also needed to determine whether preformed enzymes were present constitutively in ungerminated conidia. Tables $2-4$ show that no exudate fractions from the $10 \mathrm{mM}$ Tris- $\mathrm{HCl}$ buffer ( $\mathrm{pH}$ 7.0) extraction of ungerminated conidia exhibited either cellulase or pectinase activities when eluted from either anion- or cationexchange columns. Nor was enzyme activity found in the neutral fraction that were through both columns (data not shown). However, pectinase activity was present in the extract of ungerminated conidia which were prepared with $1 \mathrm{M} \mathrm{NaCl}$ (Table 3). In contrast, when ungerminated conidia were homogenized, the homogenates were positive for cellulase and pectinase activities, indicating that both enzymes are present constitutively in the ungerminated conidia. Since no exudate fractions eluted from either the anion- or the cation-exchange columns exhibited the presence of either enzyme (Tables 2 and 3), the enzymes are likely to be either bound tightly to the conidial walls or contained within the ungerminated conidia.

The present investigation provides the first direct evidence that conidia of $B$. graminis constitutively possess cellulases and pectinases and that germlings with mature appressoria release extracellular cellulases. Ismailova et al. ${ }^{7)}$ reported that cellulases of Aspergillus terreus were bound to mycelial cell walls. Although indirect histochemical evidence suggested the possibility that $B$. graminis produces cell wall-degrading enzymes ${ }^{1,10)}$, previous studies failed to detect cellulase production by this fungus ${ }^{5)}$. However, the location of these enzymes in conidia and germlings remains uncertain. The presence of nonspecific esterase activity, produced in association with cutinases, has been reported in other fungi $i^{9,19)}$ and is thought possibly to have a role in adhesion ${ }^{15}$. Thus cellulases and pectinases released from conidia and germlings of $B$. graminis might be related to their adhesion to host plant surfaces.

Shiraishi et al. ${ }^{21)}$ reported that the level of phenylalanine ammonia-lyase activity in barley leaves increased by $1 \mathrm{hr}$ after inoculation with $B$. graminis. Similarly, Cho and Smedegaard-Petersen ${ }^{4)}$ demonstrated that resistance was induced in barley leaves within 1 hr after inoculation with B. graminis. Such early responses of host plants might be associated with degradation products of host cell walls brought about by cutinase and cellulase activities associated with adhesion to host plant surfaces by $B$. graminis. Additionally, host cell-wall break-down products released by the action of fungal enzymes may be perceived by the fungus and provide stimuli that drive germling morphogenesis ${ }^{2,3}$. In light of the present results, the relationships between enzyme release, conidial adhesion and host-parasite mutual recognition clearly merit further investigation.
Contribution No. 136 from the Laboratory of Plant Pathology, Faculty of Bioresources, Mie University. Journal Paper number 15637 of the Purdue University Agricultural Experiment Station. This work was partially supported by Grantin-Aid for Scientific Research (A) (No. 10306004) and (B) (No. 08456025) from the Ministry of Education, Science, Sports and Culture of Japan to Kunoh, by a NATO Grant (CRG. 960671) to Nicholson and Carver and by the UK Ministry of Agriculture, Fisheries and Food.

\section{Literature cited}

1. Akai, S., Kunoh, H. and Fukutomi, M. (1968). Histochemical changes of the epidermal cell wall of barley leaves infected by Erysiphe graminis hordei. Mycopathol. Mycol. Appl. 35 : 175-180.

2. Carver, T.L.W., Ingreson-Morris, S.M. and Thomas, B.J. (1996). Influences of host surface features on development of Erysiphe graminis and Erysiphe pisi. In Plant Cuticles-An Integrated Functional Approach (Kerstiens, G. ed.), Bios Scientific Press, Oxford, pp. 255266.

3. Carver, T.L.W., Ingreson-Morris, S.M., Thomas, B.J. and Zeyen, R.J. (1995). Early interactions during powdery mildew infection. Can. J. Bot. 73 (Suppl. 1) : S632639.

4. Cho, B.H. and Smedegaard-Petersen, V. (1986). Induction of resistance to Erysiphe graminis f. sp. hordei in near-isogenic barley lines. Phytopathology 76 : 301-305.

5. Fric, F. and Wolf, G. (1994). Hydrolytic enzymes of ungerminated and germinated conidia of Erysiphe graminis DC f. sp. hordei Marchal. J. Phytopathol. 140 : 1-10.

6. Ghemawat, M.S. (1977). Polychromatic staining with toluidine blue $\mathrm{O}$ for studying the host-parasite relationships in wheat leaves of Erysiphe graminis f. sp. tritici. Physiol. Plant Pathol. 11 : 251-253.

7. Ismailova, D., Biriuzova, V. and Loginova, L.G. (1976). Localization of cellulase in the Aspergillus terreus mycelial cells. Mikrobiologia 45 : 777-780.

8. Kobayashi, I., Tanaka, C., Yamaoka, N. and Kunoh, H. (1991). Morphogenesis of Erysiphe graminis conidia on artificial membranes. Trans. Mycol. Soc. Jpn. 32 : 187198.

9. Kolattukdy, P.E. and Gamble, D.L. (1995). Nectria haematococca. In Pathogenesis and Host Specificity in Plant Diseases: Histochemical, Biochemical, Genetic and Molecular Bases, Vol. II Eukaryotes (Kohmoto, K., Singh, U.S. and Singh, R.P. eds.), Pergamon, Oxford, pp. 83-101.

10. Kunoh, H. and Akai, S. (1969). Histochemical observation of the halo on the epidermal cell wall of barley leaves attacked by Erysiphe graminis hordei. Mycopathol. Mycol. Appl. 37 : 113-118.

11. Kunoh, H., Carver, T.L.W. and Nicholson, R. L. (1997). Liquid release from conidia of Erysiphe graminis on hydrophobic or hydrophilic substrata. Ann. Phytopathol. Soc. Jpn. 63 : 509-510 (Abstr. in Japanese).

12. Kunoh, H., Nicholson, R.L., Yoshioka, H., Yamaoka, N. and Kobayashi, I. (1990). Preparation of the infection court by Erysiphe graminis: degradation of the host 
cuticle. Physiol. Mol. Plant Pathol. 36 : 397-407.

13. Kunoh, H., Yamaoka, N., Yoshioka, H. and Nicholson, R.L. (1988). Preparation of the infection court by Erysiphe graminis: I. Contact-mediated changes in morphology of the conidium surface. Exp. Mycol. 12: 125-136.

14. Mendgen, K. and Deising, H. (1993). Infection structures of fungal plant pathogens-A cytological and physiological evaluation. New Phytol. 124 : 193-213.

15. Nicholson, R.L. and Epstein, L. (1991). Adhesion of fungi to the plant cuticle. In The Fungal Spore and Disease Initiation in Plants and Animals (Cole, G.T. and Hoch, H.C. eds.), Plenum Press, New York, pp. 3-23.

16. Nicholson, R.L. and Kunoh, H. (1995). Early interactions, adhesion, and establishment of the infection court by Erysiphe graminis. Can. J. Bot. 73 (Suppl. 1) : 609-615.

17. Nicholson, R.L., Yoshioka, H., Yamaoka, N. and Kunoh, H. (1988). Preparation of the infection court by Erysiphe graminis: II. Release of esterase enzyme from conidia in response to a contact stimulus. Exp. Mycol. $12: 336-349$.

18. Pascholati, S., Yoshioka, H., Kunoh, H. and Nicholson, R.L. (1988). Preparation of the infection court by Erysiphe graminis: cutinase is a component of the conidial exudate. Physiol. Mol. Plant Pathol. 41 : 53-59.

19. Purdy, R.E. and Kolattukdy, P.E. (1975). Hydrolysis of plant cuticle by plant pathogen. Properties of cutinase I, cutinase II, and a nonspecific esterase isolated from Fusarium solani pisi. Biochemistry 14 : 2832-2840.

20. Saarilahti, H.T., Heino, P., Pakkanen, R., Kalkkinen, N., Palva, I. and Palva, E. (1990). Structural analysis of the $p h e A$ gene and characterization of its protein product, endogalacturonase, of Erwinia carotovora subspecies carotovora. Mol. Microbiol. 4 : 1037-1044.

21. Shiraishi, T., Yamada, T., Nicholson, R. L. and Kunoh, H. (1995). Phenylalanine ammonia-lyase in barley: activity enhancement in response to Erysiphe graminis $\mathrm{f}$. sp. hordei (race 1), a pathogen, and Erysiphe pisi, a nonpathogen. Physiol. Mol. Plant Pathol. 46 : 153-162.

22. Smith, H.C. and Blair, J.D. (1950). Wheat powdery mildew investigations. Ann. appl. Biol. 37 : 570-583.
23. Staub, T., Dahmen, H. and Schwinn, F.J. (1974). Lightand scanning electron microscopy of cucumber and barley powdery mildew on host and nonhost plants. Phytopathology 64 : 364-372.

24. Teather, R.M. and Wood, P.J. (1982). Use of Congo red-polysaccharide interactions in enumeration and characterization of cellulolytic bacteria from the bovine rumen. Appl. Environ. Microbiol. 43 : 777-780.

25. Widholm, J.M. (1972). The use of fluorescein diacetate and phenosafranine to determining viability of cultured plant cells. Stain Technol. 47 : 189-194.

\section{和 文 摘 要}

鈴木俊二・小宮友紀子・三井友宏・露無慎二 ・ 久能 均・Timothy L.W. CARVER ・ Ralph L. NiCHOLSON：人工膜上における Blumeria graminis 分生子の細胞壁分解酵素放出

Blumeria graminis (Syn: Erysiphe graminis) 分生子を 2 種 の疎水性人工膜（疎水性処理をしたセルロース膜およびプラス チック)上で発芽させ, 発芽胞子からの滲出物に含まれるセルラ 一ゼ，ペクチナーゼ活性を検定した。分生子を人工膜上で 1,6 および 16 時間培養し, それぞれ第一次発芽管, 付着器発芽管, 成熟付着器を形成させた。その人工膜を $10 \mathrm{mM}$ Tris- $\mathrm{HCl}$ ( $\mathrm{pH}$ 7.0) 緩衝液で洗い滲出物を回収した。回収液を陰イオン交換カ ラム, 陽イオン交換カラムに通した。前者のカラムから各濃度の $\mathrm{NaCl}$ で溶出した画分を CMC プレート法, PNPC 法で検定し たところセルラーゼ活性を示したが, PYA プレート法によるぺ クチナーゼ活性は認められなかった。このように, セルラーゼは 人工膜上で接種後 16 時間までに発芽胞子から放出された。ま た，接種後 1 および 6 時間までに放出された滲出物は弱いセル ラーゼ活性を示したが, ペクチナーゼ活性は認められなかった。 一方，分生子柄上から直接採取した未発芽胞子を同じ緩衝液て 洗った回収液中にはこれらの酵素活性は検出されなかった。し かし, 未発芽胞子を $1 \mathrm{M} \mathrm{NaCl}$ で洗った洗浄液にはペクチナー ゼ活性のみが認められた。この結果は,ペクチナーゼは分生子表 面に強く結合していることを示唆している。さらに, 分生子磨砕 物中に両酵素活性が認められ, 両酵素が胞子に構成的に存在す ることが示された。この報告はうどんこ病菌の分生子がセルラ 一ゼ,ペクチナーゼを生産し, セルラーゼが形態形成に伴って放 出されることを直接的に示す最初の報告である。 